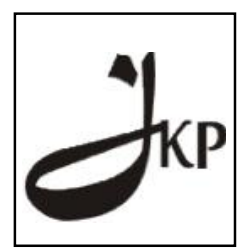

Jurnal Konseling dan Pendidikan

ISSN Cetak: 2337-6740 - ISSN Online: 2337-6880

http://jurnal.konselingindonesia.com

Volume 1 Nomor 1, Februari 2013, HIm 67-72

\title{
Peranan Bimbingan dan Konseling dalam Domain Pengembangan Diri Siswa
}

\author{
Siti Kulsum ${ }^{1 *}$ \\ ${ }^{1}$ MAN Majalaya Kabupaten Bandung - Jawa Barat
}

\begin{abstract}
Layanan Bimbingan dan konseling sekolah merupakan salah satu bentuk layanan interpersonal. Yang memiliki posisi strategis untuk membantu siswa dalam mengatasi masalah yang dihadapinya dan mempunyai peranan dalam memfasilitasi perkembangan serta potensi yang mereka miliki. Penyelenggaraan layanan bimbingan dan konseling diharapkan mampu membantu individu untuk memahami diri sendiri, orang lain dan lingkungannya. Serta dapat melakukan penyesuaian-penyesuaian dalam merealisasikan fungsi-fungsi kehidupan dan memenuhi kebutuhan kebutuhannya. Guru Bimbingan dan Konseling sebagai bagian integral dari pendidikan nasional Indonesia, mestinya tidak hanya berpikir tentang penanganan masalah-masalah patologis atau masalah-masalah meladjusment yang sifatnya kuratif saja. Layanan Bimbingan dan Konseling mesti lebih luas lagi, yaitu pengembangan diri siswa secara komprehensif, sebagaimana yang diharapkan Negara dalam UU pendidikan sehingga Guru Pembimbing dengan sadar memberikan kontribusi bagi peningkatan martabat bangsa, citra bangsa di dunia internasional. Sejalan dengan UU No. 20/2003 dan Renstra Depdiknas, Sunaryo (1996 dan 2009a) mengemukakan bahwa pelaksanaan bimbingan dan konseling harus berupa intervensi sistematik dan sistemik terhadap perkembangan paribadi manusia yang terorganisasikan, terstruktur, dan terlembagakan di dalam pendidikan. Pengembangan pribadi itu meliputi pengembangan kecerdasan diri, kecerdasan emosional, kecerdasan sosial, kecerdasan moral, dan pengetahuan diri (self-knowledge) yang akan menjadi kekuatan dalam diri manusia untuk mencegah timbulnya perilaku bermasalah di dalam masyarakat..
\end{abstract}

Keyword: Bimbingan Konseling, Pengembangan Diri

Copyright (C) 2013 IICE - Multikarya Kons - All Rights Reserved Indonesian Institute for Counseling and Education (IICE) Multikarya Kons

\section{PENDAHULUAN}

Pendidikan adalah usaha sadar dan terencana untuk mewujudkan suasana belajar dan proses pembelajaran agar peserta didik secara aktif mengembangkan potensi dirinya untuk memiliki kekuatan spiritual

\footnotetext{
*Telp dan/atau Alamat Email Koresponden : 'Email: sitikulsum85@gmail.com
} 
Jurnal Konseling dan Pendidikan

keagamaan, pengendalian diri, kepribadian, kecerdasan, ahlak mulia, serta keterampilan yang diperlukan dirinya, masyarakat, bangsa dan Negara (Pasal 1 ayat 1 UU 20 Tahun 2003 tentang SPN)

Image tentang Bimbingan dan Konseling yang beredar di kalangan siswa, bahwa Bimbingan dan Konseling adalah polisi sekolah, takut dan ngeri kalau dipanggil harus sudah tidak ada lagi. Faktor lain yang membuat tidak nyamannya siswa berhubungan dengan guru Bimbingan dan Konseling adalah lokasi dan infastruktur ruangan. Masih banyak sekolah yang menempatkan ruangan Bimbingan dan Konseling bukan merupakan ruangan yang penting, contohnya letaknya di pojok belakang sekolah. Kondisinya sempit, tidak nyaman dan sangat tidak memadai untuk proses kegiatan konseling. Selanjutnya peran dari guru Bimbingan dan Konseling itu sendiri dituntut harus profesional dan mempunyai jiwa sabar, ikhlas dan mau berkorban untuk suatu perubahan anak didik untuk mengembangkan poensinya maupun membantu mereka yang menemui kendala. Ujung-ujungnya yang sangat strategis adalah peran kepala sekolah yang harus mempunyai visi tentang Bimbingan dan Konseling yang merupakan tangan kanannya untuk mencapai tujuan pendidikan.

Perkembangan informasi global dan kompleksitas tatanilai kehidupan sejatinya mendorong peran guru Bimbingan dan Konseling untuk lebih proaktif memiliki pengetahuan yang meningkat. Tidak stagnan. Guru Bimbingan dan Konseling tidak boleh tertinggal dengan strategi canggih yang dipasang oleh siswa. Seperti dalam hal adu argumentasi, pemahaman dan penguasaan teknologi,kedustaan untuk mengecoh dalam berbagai tindakan penyimpangan.

\section{PELAYANAN BIMBINGAN DAN KONSELING PADA PENGEMBANGAN DIRI BIDANG AKADEMIK}

Bimbingan dan Konseling bukan merupakan mata pelajaran artinya guru Bimbingan dan Konseling tidak mengajar, tidak memberikan nilai kuantitatif untuk raport namun demikian bukan berarti mereka tidak memiliki peranan pada bidang akademik. sebaliknya guru Bimbingan dan Konseling merupakan ujung tombak penunjang keberhasilan peserta didik pada bidang akademik. Pelayanan Bimbingan dan Konseling pada bidang akademik dimulai dari hari pertama peserta didik memasuki sekolah, dengan tujuan agar mereka dapat mengembangkan potensi dirinya pada bidang akademik.

Pada Masa Orientasi Penerimaan Peserta Didik Baru (MOPD) guru Bimbingan dan Konseling memberikan pelayanan dalam bentuk pemberian informasi tentang kurikulum, diantaranya : macam-macam mata pelajaran yang akan diikuti oleh peserta didik selama tiga (3) tahun pembelajaran, persyaratan nilai yang harus dipenuhi, wawasan tentang lingkungan sekolah meliputi sarana prasarana, (perpustakaan, laboratorium, dan lain-lain), struktur organisasi sekolah, personil sekolah dan sebagainya, yang dapat menunjang keberhasilan pengembangan diri mereka pada bidang akademik.

Selanjutnya layanan Bimbingan dan konseling pada bidang akademik selama proses pembelajaran berlangsung, diantaranya adalah bimbingan belajar, penempatan dan penyaluran, serta bagi siswa yang duduk di kelas sepuluh (X) semester dua (2) dilakukan penjurusan. Untuk penjurusan guru Bimbingan dan Konseling bekerjasama dengan biro psikologi yang melaksanakan psikotes, agar penjurusan sesuai dengan bakat, minat serta tingkat kecerdasan siswa.

Untuk siswa SMA sederajat yang duduk di kelas XII, pelayanan Bimbingan dan Konseling lebih mengarah kepada pengembangan karier, meliputi informasi berbagai macam jurusan di perguruan tinggi dan informasi dunia kerja karena tidak semua lulusan bisa melanjutkan ke perguruan tinggi. Disini diinformasikan persyaratan untuk memasukinya serta prospek masa depan dari suatu perguruan tinggi maupun bidang pekerjaan yang akan dimasukinya. Disamping itu berbagai macam jabatan serta persyaratannya juga merupakan informasi penting yang diberikan oleh pelayanan Bimbingan dan Konseling bagi siswa di SMA kelas XII.

Bagi peserta didik yang mengalami kesulitan pada bidang akademik (baik untuk kelas X, XI maupun XII), guru Bimbingan dan Konseling melakukan konseling individual maupun konseling kelompok. Konseling yang dilakukan biasanya mengenai masalah belajar yang baik, cara membagi waktu, pemilihan jurusan yang sesuai dengan bakat dan minat, cara mengatasi kesulitan belajar, masalah kehadiran siswa di kelas, merencanakan masa depan, dan sebagainya. Dalam menangani masalah kesulitan belajar, guru Bimbingan dan Konseling bekerjasama dengan guru bidang studi, termasuk untuk pelayanan remedial. 
Jurnal Konseling dan Pendidikan

\section{PELAYANAN BIMBINGAN DAN KONSELING PADA PENGEMBANGAN DIRI BIDANG NON AKADEMIK}

Seting Pelayanan Bimbingan dan konseling bukan hanya diberikan pada bidang akademik, namun juga dilaksanakan pada bidang non akademik. Tujuan dari pelayanan ini adalah untuk mengembangkan potensi siswa pada bidang non akademik, sehingga bakat maupun minat peserta didik dapat berkembang secara optimal.

Pada saat Masa Orientasi Peserta Didik Baru (MOPD) guru Bimbingan dan Konseling bekerjasama dengan kesiswaan menyebarkan angket minat untuk peserta didik baru pada bidang non akademik, khususnya untuk kegiatan ekstra kurikuler. Angket tersebut sudah disusun berdasarkan identifikasi kebutuhan siswa, dengan patokan tahun sebelumnya. Kemudian angket tersebut dianalisa serta disesuaikan dengan kekuatan dan kelemahan sekolah dengan menggunakan analisis SWOT (Strenght, Weakness, Opportunity, Threats). Kegiatan serupa dilaksanakan untuk peserta didik kelas XI dan XII, dengan pertimbangan apakah mereka akan tetap mengikuti kegiatan ekstra kurikuler yang sama atau akan berubah/pindah ke kegiatan ekstra kurikuler yang lain.

Selanjutnya pelayanan Bimbingan dan konseling dilaksanakan melalui konseling individual/kelompok bagi siswa yang memiliki masalah dalam kegiatan ekstra kurikuler yang sedang dijalaninya.

\section{PELAYANAN BIMBINGAN DAN KONSELING PADA PENGEMBANGAN DIRI BIDANG PSIKOLOGIS}

Pemahaman aspek psikologis siswa pada institusi pendidikan memiliki kontribusi yang sangat berarti dalam pengembangan aspek kognitif, afektif dan psikomotorik. Hal ini sesuai dengan karakteristik siswa yang unik dilihat dari segi perilaku, kepribadian, sikap, minat motivasi, perhatian, persepsi, daya pikir, intelegensi, fantasi, dan berbagai aspek psikologis yang berbeda antara siswa yang satu dengan yang lain.

Tidak ada dua individu yang sama. Perbedaan karakteristik psikologis siswa harus dipahami oleh semua guru. Namun kenyataan tidak semua guru dapat memperhatikan hal tersebut, apalagi guru mata pelajaran yang sering kali dikejar dengan target kurikulum yang harus dipenuhi.

Pelayanan Bimbingan dan Konseling pada bidang psikologis meliputi pengembangan pribadi siswa pada bidang psikologis seperti pemahaman terhadap diri sendiri, konsep diri, minat, bakat, kemampuan, sikap, sifat dan sebagainya. Pelayanan ini bertujuan agar siswa lebih memahami dirinya, sehingga dapat berkembang sesuai dengan potensi yang dimiliki.

\section{MENUJU GENERASI MANDIRI, KREATIF DAN INOVATIF}

Dalam banyak kasus, proses belajar mengajar di Indonesia cenderung menghambat kreativitas atau terkadang menghilangkan daya imajinasi siswa.belajar masih banyak terfokus di kelas, keunikan anak sebagai pribadi cenderung kurang dihargai karena pihak guru menuntut keseragaman jawaban atas persoalan yang diajukannya. Berfikir divergen, atau yang menghargai perbedaan dalam mengekspresikan pendapat terhadap suatu cara penyelesaian masalah seringkali ditutup. Kemampuan untuk menjelajahi berbagai alternatif kurang dipupuk . Akhirnya yang berkembang adalah justru kekakuan.

Memasuki dunia kompetisi global, sekolah idealnya harus mampu menciptakan sistem yang mengembangkan lingkungan asuh yang memacu siswa agar terbuka terus menerus terhadap perkembangan. Sistem pendidikan yang lebih menekankan hanya kepada daya nalar harus diimbangi dengan kegiatan yang merangsang daya kreativitas serta kecerdasan emosi. Sedini mungkin sekolah harus mampu menerapkan proses belajar yang mengembangkan nilai-nilai kemandirian, daya kreativitas, daya inovasi, serta kerjasama.

Proses belajar mengajar selayaknya lebih mengembangkan ranah kompetensi yang akan dibutuhkan dalam dunia nyata kompetisi. Melalui kegiatan bidang akademik, non akademik, maupun bimbingan pengembangan diri bidang psikologis, potensi siswa yang dikembangkan tidak saja hard competence (kompetensi yang terlihat, misalnya nilai akademis pelajaran), tetapi juga soft competence (kompetensi yang tidak terlihat). Pengembangan aspek nalar harus diimbangi juga dengan pengembangan kecakapan lain seperti orientasi akan pencapaian atau daya juang (Achievement orientation), kecakapan akan pencarian informasi (Information seeking), kecakapan berfikir secara konseptual (Conceptual thinking), kemampuan berfikir analitis (Analytical Thinking), Inisiatif 
Jurnal Konseling dan Pendidikan

(Initiative), kemampuan bekerjasama dengan orang lain (Teamwork) serta kemampuan memahami orang lain (Interpersonal understanding).

Pengembangan hard competense dan Soft Competence seperti diuraikan di atas harus mampu disajikan kepada siswa melalui suatu kemasan methodologi yang menarik, menantang, variatif, tetapi secara ekonomis terjangkau untuk diterapkan.

\section{TIGA PILAR UTAMA PENDIDIKAN}

Sukses bukanlah hanya sebuah fantasi namun merupakan suatu formula, bukan tujuan, tetapi sebuah perjalanan. Untuk menjadi sukses maka dia harus mengetahui visi hidupnya, menyadari dan terus tumbuh serta berkembang menuju potensi maksimal. Tiga faktor utama yang mempengaruhi keberhasilan suksesnya pembelajaran siswa di sekolah adalah guru, orang tua, dan siswa.

Ketiga pilar di atas harus memiliki pemahaman / internalisasi yang sama tentang arah dan tujuan akhir dari sistem pembelajaran. Ketika peraturan menteri tahun 2006 menggariskan bahwa tujuan dari pengembangan diri adalah untuk memberikan kesempatan kepada siswa mengembangkan dan mengkekspresikan diri sesuai dengan potensi siswa, maka pihak sekolah berkewajiban menyediakan program yang teritegrasi dan fasilitas yang mendukungnya, orang tua mencukupi dan mendukung konsekuensinya, serta siswa dengan ikhlas dan penuh kesungguhan dan tanggungjawab mengikutinya.

Permasalahan yang paling utama dalam bimbingan dan konseling adalah kurangnya pemahaman tersebut dari pihak terkait. Peran bimbingan dan konseling sering didefinisikan terlalu sempit sebagai tempat membina siswa berperilaku menyimpang (bermasalah). Seorang siswa yang dipanggil untuk konseling seolah dia yang memiliki masalah baik prestasi akademis maupun psikologis.

\section{PERAN BIMBINGAN DAN KONSELING DALAM MENGEMBANGKAN POTENSI SISWA}

Dari uraian di atas, nampak bahwa pengembangan diri siswa dimulai dengan merancang program untuk optimalisasi potensi ketiga pilar yakni guru, orang tua, dan siswa. Untuk itu peran guru bimbingan dan konseling menjadi sangat sentral dalam sebuah sekolah.

\section{Guru Bimbingan dan Konseling sebagai Agen Perubahan (Change Agent)}

Ada dua kutipan menarik untuk menjelaskan betapa pentingnya peran seorang guru Bimbingan dan Konseling memahami perubahan. "Nothing is permanent but change. You cannot step twice into the same river, for other waters are always flowing in". (Heraclitus).

Tak ada yang tetap kecuali perubahan, kita tak bias melangkah masuk ke dalam sungai yang airnya sama karena air yang lain selalu mendesak mengalir yang sebelumnya. " Our real problem, then, is not our strength today; it is rather the vital necessity of action today to ensure our strength tomorrow." (Dwight D. Eisenhower).

Masalah kita sebenarnya bukanlah kekuatan kita pada hari ini; tetapikepentingan mendesak untuk melakukan sesuatu pada hari ini yang bisa menjamin kekuatan kita esok hari

Memahami perannya yang sentral, tugas guru bimbingan dan konseling yang harus dilakukan pertama kali adalah memahami dan memaknai tentang langgengnya proses perubahan. Dengan menyadari hal tersebut, selanjutnya dirinya diharapkan mampu menyesuaikan dengan perubahan itu, dan selanjutnya barulah dia bisa diharapkan menjadi change agent atau agen perubahan bagi yang lain.

Seorang guru bimbingan dan konseling harus terbiasa mengidentifikasi tentang tantangan bangsa masa depan di segala bidang, selanjutnya dia analisis apa saja yang akan menjadi kesempatan dan tantangan bagi siswa nya di kemudian hari, dan terakhir dia akan tuangkan hasil analisis itu dalam program program pengembangan diri yang harus diikuti siswa untuk menghadapi tantangan tersebut.

Dia akan senantiasa belajar dan belajar untuk mengubah dirinya sehingga kemampuan, ketrampilan, wawasan, dan kepribadiannya tumbuh dan berkembang. Perubahannya akan dia transformasikan kepada orang lain di sekelilingnya sesuai dengan peran dan fungsinya di lingkungannya. 
Jurnal Konseling dan Pendidikan

Sebagai agen perubahan, maka dia harus memprioritaskan untuk meletakkan landasan yang kokoh kepada guru, siswa, dan orang tua. tentang paradigma belajar. Untuk itu diperlukan pengetahuan yang memadai, keberanian, dan keuletan yang ditunjang oleh kemampuan komunikasi serta kepribadian.

Seorang guru Bimbingan dan Konseling harus memiliki program yang berkesinambungan dan variatif untuk menanamkan paradigma belajar ini dan yakin bahwa konsep tersebut dilaksanakan dalam keseharian. Saat paradigma belajar sudah difahami semua pihak, selanjutnya guru Bimbingan dan konseling harus membangun sistem yang memfasilitasi semua kegiatan sedang menuju kepada optimalisasi tercapainya tujuan pembelajaran. Guru Bimbingan dan Konseling harus mampu menciptakan standar, prosedur, buku pedoman, buku panduan, manual, format, serta formulir sebagai acuan para guru dan siswa dalam melaksanakan program. Namun demikian, standarisasi ini tetap dimaksudkan untuk meyakinkan bahwa semua program sejalan dengan tujuan pembelajaran dan bukan untuk mempersulit guru atau memasung kreativitas.

\section{Guru Bimbingan Konseling Sebagai Integrator}

Potensi yang tersimpan pada para guru, orang tua, dan siswa harus mampu dikemas bimbingan dan konseling menjadi sebuah program yang mengembangkan kompetensi siswa sesuai dengan bakat, minat dan kemampuannya.

Guru bimbingan dan konseling harus mengetahui lebih awal tentang profil siswa dan guru. Dia harus mengenali secara umum, berada pada kwadran manakah para siswanya, apakah dia termasuk type promotor, fasilitator, analytical, atau controller.

Setelah guru bimbingan dan konseling mengidentifikasi masing masing siswa, maka kewajibannya adalah mengembangkan segala hal yang positif yang ada pada diri siswa dan meminimumkan hal-hal negatif. Melalui program yang telah dipersiapkan, guru bimbingan dan konseling harus memanfaatkan potensi guru, para orang tua, bahkan para alumni untuk dapat menggali dan mengembangkan potensi masing masing siswa sesuai kondisi psikhologisnya.

Sebagai integrator, dia harus faham bahwa setiap siswa memiliki potensi dan bisa dikembangkan secara optimum sesuai dengan kapasitasnya. Kompetensi siswa harus difasilitasi dengan suhu, tanah, dan lingkungan yang kondusif untuk partumbuhannya.

\section{Program Pengembangan Potensi Siswa}

Program yang baik idealnya dilakukan dengan memperhatikan masing-masing siswa sebagai individu yang unique atau berbeda satu sama lainnya. Dalam beberapa hal kondisi ini bisa dilaksanakan. Meskipun tak jarang juga sulit dilaksanakan dalam banyak hal mengingat kendala siswa, guru, dan kemampuan sekolah.

Banyak program pengembangan diri yang bagus jika dilaksanakan, namun memerlukan biaya yang sangat mahal. Berikut ini beberapa hal yang bisa dilakukan dengan mempertimbangkan biaya, fasilitas, dan keahlian yang terjangkau:

1. Perbaikan terhadap proses belajar mengajar yang menekankan pada kebermaknaan

- Penugasan yang mengembangkan aspek pengembangan diri selain pengembangan nalar.

- Make the students learn by themselves untuk kreativitas, cukup berikan rambunya saja.

- Berikan tugas yang menantang dan attractif, hubungkan dengan kondisi lingkungan makro (perkembangan di masyarakat).

- Buatkan siswa presentasi tentang penemuan, hasil wawancara dsb.

- Buatkan majalah dinding yang menantang dan attractif.

- Majalah sekolah yang menantang.

- Hidupkan kegiatan pembelajaran yang ilmiah.

- Outward bound kepemimpinan yang diselenggarakan oleh alumni.

- Penyelenggaraan seminar rutin oleh siswa tentang aktualisasi diri.

- Penyelenggaraan pelatihan dengan melibatkan ahli sebagai nara sumber.

- Mengikuti berbagai kompetisi. 
Jurnal Konseling dan Pendidikan

2. Program Ekstrakurikuler

- $\quad$ Bidang seni

- Bidang olah raga

3. Menjalin kerjasama dengan berbagai pihak

- Kerjasama dengan instansi terkait;

- Kerjasama dengan berbagai perguruan tinggi baik negeri maupun swasta;

- Mencari sponsor sebagai pendukung berbagai kegiatan untuk menekan pembiayaan.

\section{DAFTAR PUSTAKA}

Depdiknas R.I. (2006). Ringkasan Eksekutif Renstra Departemen Pendidikan Nasional Tahun 2005-2009 Menuju Pembangunan Pendidikan Nasional Jangka Panjang 2025.

Depdiknas. (2008). Penataan Pendidikan Profesional Konselor dan Layanan Bimbingan dan Konseling Dalam Jalur Pendidikan Formal.

Dirjen PMPTK Depdiknas. (2007) Rambu-Rambu Penyelenggaraan Bimbingan dan Konseling Dalam Jalur Pendidikan Formal.

E. Mulyasa, M.Pd. 2008. Kurikulum Berbasis Kompetensi. Bandung. PT. Remaja Rosdakarya.

Suherman, M.Pd dkk. 2008. Konsep dan aplikasi Bimbingan dan Konseling. Bandung. Universitas Pendidikan Indonesia

Suryani, Yeni. 2008. Makalah Korelasi Antara Peran BK dengan Optimalisasi Potensi Siswa untuk Menghadapi Tuntutan Perubahan Lingkungan. Jakarta. 